\title{
滑走路グルービングの航空機荷重に対する 安定性
}

\author{
八谷 好高 $^{1} \cdot$ 坪川 将丈 ${ }^{2}$ \\ 1 フェロー会員 独立行政法人 港湾空港技術研究所空港研究センター（†239-0826 横須賀市長瀬3-1-1） \\ E-mail : hachiya@ipc.pari.go.jp \\ 2 正会員 国土交通省 国土技術政策総合研究所空港研究部（干239-0826 横須賀市長瀬3-1-1） \\ E-mail : tsubokawa-y92y2@ysk.nilim.go.jp
}

空港滑走路におけるグルービングの航空機荷重に対する安定性について研究し, それを保持するために 必要となる方策について明らかにした. まず, 現地調查と数值解析の結果に基づき, すべり抵抗性を確保 するという滑走路の要求性能を満足するためには, グルービングの溝の容積減少率を $20 \%$ 以内に抑えるこ とが必要であることを見出した。 そして，一連の室内試験を行った結果に基づいて，これを可能ならしめ る具体策は，表層アスファルトコンクリートに改質アスファルトを使用することであることを明らかにし た. これに加えて，オーバーレイの場合にはストレートアスファルトを用いたとしても，骨材面での工夫 をした上である程度の養生期間を確保することで対応しうることがわかった。

Key Words: grooving, runway, asphalt pavement, durability, laboratory test

\section{1. はじめに}

空港滑走路のすべり抵抗性を維持することは，航空機 の運航の安全性を確保する上で重要な要求性能の一つで ある.このすべり抵抗性は滑走路面が湿潤状態となって いると著しく低下するので，降雨時においては滑走路か ら雨水を速やかに排除することが肝要である。そのため に，滑走路の横断方向に勾配を付けるとともにグルービ ングを設けるという対策を採っている1).

このグルービングの効果はタイヤゴム付着により低下 する ${ }^{2)}$ が, グルービングの溝が航空機の繰返し走行を受 けて変形することによっても低下する. この問題に対処 するために，表層アスファルトコンクリートを施工後2ヶ 月以上経過してから，グルービングを設置することが規 定されている3)。これは1970，1980年代に行われた室内 試験 ${ }^{4)}$ や現地調査 ${ }^{5), 6)}$ 結果に基づいて定められたもので ある．室内試験では，アスファルトコンクリートの材料 や施工後グルービングを設置するまでの期間を変えた場 合のグルービングの安定性に関して基礎的な検討が行わ れた，現地調査では，グルービングの変状は，滑走路の 末端ならびに高速脱出誘導路の手前における溝のつぶれ (変形) と施工目地における角欠けが主たるものである こと，室内にて新たに作製した試料に比べて供用中の空 港滑走路から採取されたもののほうがグルービングの安
定性が高いことが室内試験により見出されている.

上記のように表層アスファルトコンクリートを施工後 2 ケ月経過してからグルービングを設けてはいるが，大規 模空港を始めとしたいくつかの空港においては依然とし てグルービングの溝の変形がみられている.このことは, 現行規定は溝形状を保持する上ではいくらか効果がある ものの，決して十分とは言えないことを示唆しているも のと思われる. 特に, 近年は航空機が大型化し, また運 航回数も増加していることから，グルービング溝の変形 の進行，ひいては航空機の運航安全性の低下が懸念され るところである。また，現行規定に従えば供用中の空港 滑走路に対してオーバーレイ等の大規模補修を施す場合 であっても，施工後少なくとも2ヶ月間はグルービングを 設置できないことになるが，これは，場合によっては， 航空機の運行安全性確保上問題となりかねない.

以上のことを背景として，航空機荷重に対するグルー ビングの安定性向上方策を明らかにするための研究を実 施した。 具体的には，まず，グルービングの溝の変形が グルービングの効果に及ぼす影響について明らかにした. 次に，グルービングの安定性について，アスファルトコ ンクリートの材料そのものならびに表層施工後グルービ ングを設置するまでの期間を要因として室内試験により 検討した，そして，これらの結果に基づき，滑走路新設 時とオーバーレイ時においてグルービングの所要性能を 
表-1 すべり抵抗性 (摩擦係数) の管理目標值

\begin{tabular}{|c|c|c|c|c|}
\hline \multirow{2}{*}{ 試験装置 } & \multicolumn{2}{|c|}{ グルービング } & \multirow{2}{*}{$\begin{array}{c}\text { 速度 } \\
(\mathrm{km} / \mathrm{h})\end{array}$} & \multirow{2}{*}{ タイヤ } \\
\hline & 有 & $\begin{array}{l}\text { 無 } \\
\end{array}$ & & \\
\hline 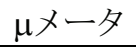 & 0.6 & 0.5 & 60 & - \\
\hline \multirow{2}{*}{ SFT } & 0.55 & 0.45 & 95 & 低圧 \\
\hline & 0.45 & 0.4 & 95 & 高圧 \\
\hline
\end{tabular}

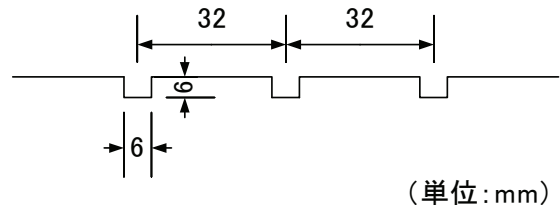

図-1 グルービングの形状

満足寸るための方策について明らかにした，なお，本論 文において使用しているグルービングの安定性とは，特 に断らない限り,グルービングの溝形状の保持性能を意 味している.

\section{2. グルービングによる航空機の走行安全性の向上}

\section{（1）空港舗装のグルービングに関する規定}

滑走路が湿潤状態となったときの航空機の走行安全性 を確保するために, 湿潤時のす心゙り抵抗性については, 国際民間航空機関 (International Civil Aviation Organization, ICAO) により規定が設けられている7)。わが国でも表-1 に示すような管理目標值が提案されている ${ }^{8)}$.

このような規定を満足するために，ICAOは，排水性を 高めることを目的として，必要に応じて滑走路横断方向 にグルービングを設けることを定めている ${ }^{9}$ ．わが国の場 合は，これをさらに進めて，滑走路の全長にわたってグ ルービングを施工することを原則としている ${ }^{1)}$. わが国で 用いられているグルービングは，図-1に示寸ように，幅 $6 \mathrm{~mm}$ ，深さ $6 \mathrm{~mm}$ の溝を $32 \mathrm{~mm}$ 間隔で滑走路中央部分の幅 員の $2 / 3$ 以上の範囲に横断方向に設けるというものである

\section{（2）すべり抵抗性に対する影響因子}

グルービング溝の変形がみられている空港滑走路から 採取した試料を用いて，すべり抵抗性に影響を及ぼす要 因について検討した.

\section{a) 試験方法}

供用を終了した東京国際空港旧B滑走路から表層部分の アスファルトコンクリート試料を採取した。 これは，グ ルービングを設けていない箇所と設けている箇所（4地 点）で行った．後者の場合は，溝の変形程度を目視によ り，なし，小，中，大と判定して試料の採取箇所を選定 した．試料の寸法は縦 $50 \mathrm{~cm}$ ，横 $110 \mathrm{~cm}$ であり，これを
表-2 試料の表面形状

\begin{tabular}{c|c|c|c|c|c}
\hline グルービング & なし & \multicolumn{4}{|c}{ あり } \\
\hline 溝の変形 & - & なし & 小 & 中 & 大 \\
\hline MPD $(\mathrm{mm})$ & 1.44 & 3.38 & 2.11 & 1.99 & 1.30 \\
きめ深さ $(\mathrm{mm})$ & 2.90 & 5.82 & 4.11 & 4.11 & 3.71 \\
\hline
\end{tabular}

縦・横 $50 \mathrm{~cm}$ の矩形に整形して，後述するすべり抵抗性測 定試験に供した.

供試体の表面形状は，プロファイルを直接測定する方 法とサンドパッチ法 ${ }^{10)}$ を用いて測定することにより定量 化した．前者では，レーザー距離計（スポット径 $0.07 \mathrm{~mm}$, 分解能 $0.003 \mathrm{~mm}$ ）を用いて， $15 \mathrm{~cm}$ 間隔で設けた 3 測線に沿 って横断方向に $0.1 \mathrm{~mm}$ 間隔でプロファイルを測定した. この結果は平均きめ深さ (Mean Profile Depth, MPD) とし て定量化した. なお， MPDは，参考文献 ${ }^{11)}$ を参考にして, プロファイルの平均位置（高さ）から最も離れたプロフ アイル上の点までの距離として定義した．後者の場合も， 上記の測線上の3箇所にて測定を実施し, 結果はきめ深さ として定量化した．それらをまとめた表-2から目視による 評価結果はほぼ妥当なものであったことが確認された.

これらの供試体表面において小型測定装置によりす心゙ り抵抗性を計測した。 具体的には, DFテスタ ${ }^{12)}$ と振り子 式測定機 ${ }^{10)}$ を使用し，供試体表面の水深が一定となるよ うに供試体端部に工夫を施した上で，水深を1～5 $\mathrm{mm}$ 範 囲で変えて試験を行った。前者の場合は測定速度を 60km/h とした. また, 後者の場合は, 航空機の走行方向 を考えてグルービングの直角方向で測定を実施した.

\section{b) 溝の変形程度, 水深とすべり抵抗性}

すべり抵抗性に関する一連の試験結果を図-2に示した。 これからDFテスタ，振り子式測定機による測定結果で

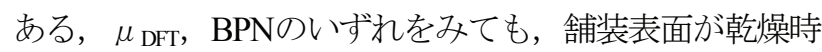
と湿潤時ですべり抵抗性は大きく異なることがわかる. また，水深が1〜 $5 \mathrm{~mm}$ 範囲で変わってもすべり抵抗性に はほとんど違いのないこともわかる。一方，車両型式の 測定装置により測定したすべり抵抗性は，舗装表面が乾 燥から湿潤状態に変わる場合, 水深が比較的浅い範囲で 急激に低下寸ること, また高速時ほど水深増加に伴って 大きく低下寸ることがわかっている ${ }^{13)}$ 。このことから， 航空機のタイヤ寸法, 走行速度を勘案すると, 湿潤状態 の滑走路上の航空機走行時のすべり抵抗性を確保するた めには, 水深を可能な限り浅く保持することが肝要であ るとわかる。

また，この図から，舗装面が湿潤状態であれば，グル ービング溝に変形が生じてもすべり抵抗性にはあまり違 いがみられないばかりか, グルービングの有無によって も大きな差はないことがわかる，このことは，今回の試 験条件下，才なわち水深を一定に保った状態においては, グルービング溝による程度の舗装表面のテクスチャの影 


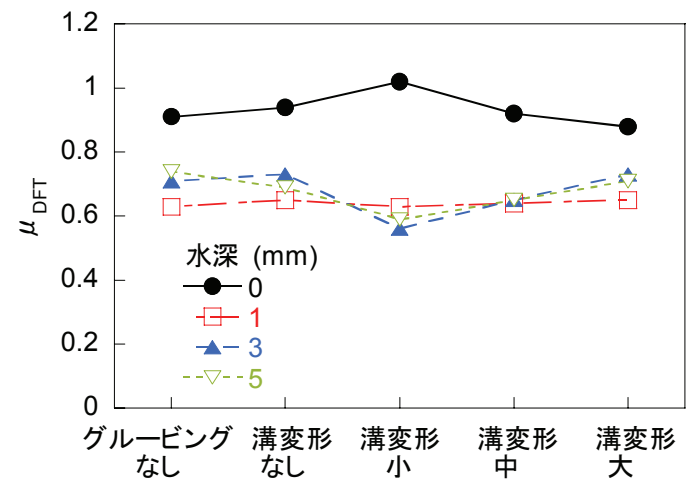

a) DFテスタ

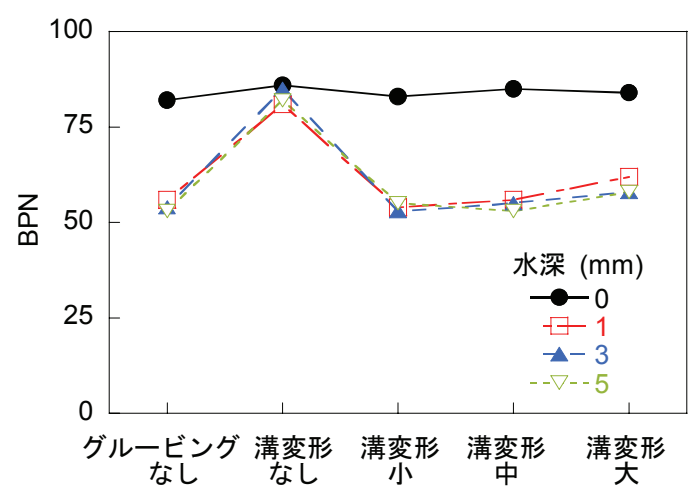

b) 振り子式測定機

図-2 すべり抵抗性の測定結果

響はここで用いた装置によるすべり抵抗性の測定結果に は現れにくいことを意味しているものと思われる，ただ し, 溝変形のない場合の湿潤時における振り子式測定機 による測定值は例外で，他に比べて高いすべり抵抗性が 保持されていることが示されている。これは，振り子式 測定機ではグルービング直角方向に測定を行うのに対し， DFテスタでは円周に沿った方向に測定を行ってそれを平 均して測定值としていることから，溝変形のない場合に 溝の角ばりが保持されている点が振り子式測定機により 評価されたためであると思われる。

一方，車両形式の測定装置を用いた供用中の空港滑走 路における測定結果には，グルービングを施工すること によるすべり抵抗性の改善が明確にみられている ${ }^{1)}$. また 特にすべり抵抗性が小さくなっている部分については, 車両形式の測定装置による測定值は振り子式測定機によ るものよりもDFテスタによるものと傾向が合致するこ

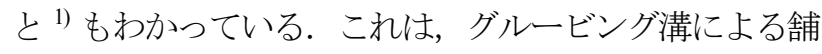
装表面のテクスチャの効果もあろうが，現地測定におい ては散水することにより水深がほぼ1 $1 \mathrm{~mm}$ とるように調 整しているものの, 室内試験の場合と異なり, グルービ ング溝の存在あるいはその健全度に応じて水深がいく分 浅くなる方向に変化してしまうことも要因の一つと思わ れる.このことから，今回試験した範囲ではあるが，舗 装表面が1mm以上に滞水していればグルービング溝の変
形状態によってすべり抵抗性が変化するようなことはほ とんどないものと推測される.

以上述べた試験結果は，グルービング溝に変形のみら れる滑走路表面が湿潤状態になると，そのすべり抵抗性 は，低下寸るものの，水深が1〜 $5 \mathrm{~mm} の$ 範囲で変化しても， またグルービング溝が今回の試験に用いたもの程度に変 形したとしても大きくは異ならないとまとめられる。 こ の結果と車両形式の測定装置によるすべり抵抗性測定結 果を勘案すると, 航空機走行時のすべり抵抗性を確保す るためには，滑走路表面におけるグルービング溝の変形 を可能な限り抑えるとともに，滞水部分の水深を可能な 限り浅くすることが必要であると結論づけられる.

\section{(3) 溝変形が降雨時の滑走路表面水深に及ぼす影響}

降雨時における滑走路の滞水（排水）状態を数值解析 により検討し，すべり抵抗性を確保するために必要とな るグルービングの要求性能を明らかにする.

\section{a) 滑走路表面水深の計算方法}

関東地区にある空港を想定して，現在わが国で標準と して用いられているグルービングの溝形状が供用中に変 化した場合の降雨時における水深を試算した，その計算 方法としては，参考文献 ${ }^{14)}$ に記されたもの，すなわち滑 走路の横断方向への雨水排水状態を開水路における定常 流として解析する方法を用いた. 入力可能な条件は次の とおりである. 具体的な入力值は可能な限り空港土木施 設設計基準 ${ }^{1)}$ に示されているとおりに決定したが，それ 以外のものについては適切に值を定めた.

1) 滑走路の片側幅員排水長 : $30 \mathrm{~m}$

2) グルービング設置範囲 : $20 \mathrm{~m}$ （滑走路片側, 中心寄 り)

3) 横断勾配: $1.0 \%$

4) きめ深さ: $0.25 \mathrm{~mm}$

5) グルービングの形状 : 幅 $6 \mathrm{~mm}$, 深さ $6 \mathrm{~mm}$ の矩形の溝を $32 \mathrm{~mm}$ 間隔で設置．溝容積変化率は $0 \%$ （健全），30\%， 58\%，83\%（変化率の定義は3.のものと同じ）．

6) 降雨強度 : 空港排水施設 - 地下道 - 共同溝設計要領 ${ }^{15)}$ にある東京地区の60分降雨強度（50年，10年確率に相 当する $90 \mathrm{~mm} / \mathrm{h}, 60 \mathrm{~mm} / \mathrm{h})$. このほかに, $30 \mathrm{~mm} / \mathrm{h}$.

\section{b) 溝の形状保持に関する要求性能}

グルービングのない場合とある場合で，降雨強度 $60 \mathrm{~mm} / \mathrm{h}$ の条件下での計算結果を図-3に示寸，グルービン グなしの場合は，滑走路中心から $2 \mathrm{~m}$ 程度の位置で水深は $1 \mathrm{~mm}$ に達してしまう。これに対して，グルービングを設 置することの効果は明らかで, 溝が健全な場合には中央 帯部分（滑走路中心から10mまでの範囲）には滞水しない. しかし, 溝の変形が進行し, 溝容積が減少するにつれて, 滞水範囲が滑走路中心寄りに拡大寸るとともに, 同一地 点での水深も増加していくことがわかる. 


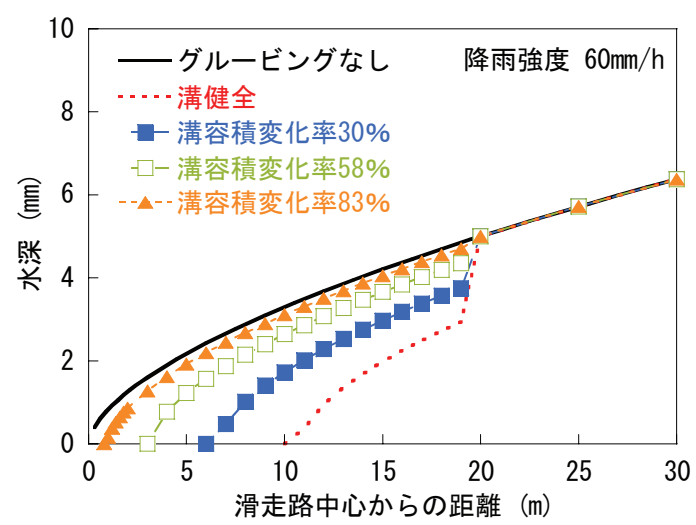

図-3グルービングの状況による水深の違い

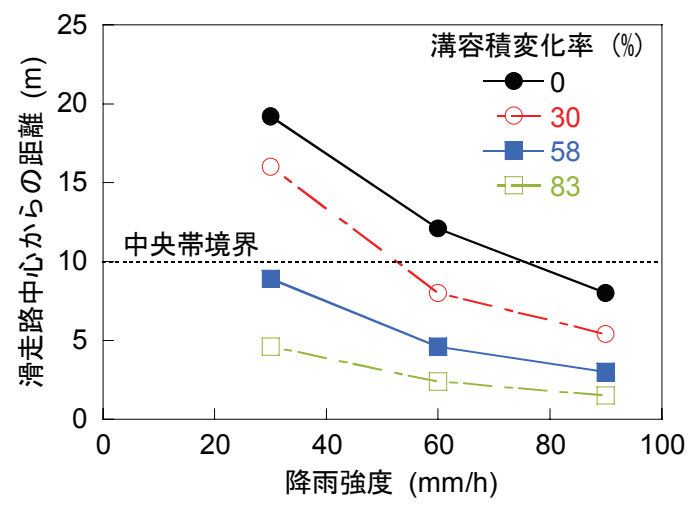

図-4 水深が1mmとなる位置（滑走路中心からの距離）

同様の計算を降雨強度 $30 \mathrm{~mm} / \mathrm{h} ， 90 \mathrm{~mm} / \mathrm{h}$ の場合について 実施した結果も用いて，水深が $1 \mathrm{~mm}$ となる位置を滑走路 中心からの距離として図-4に示した．この図から，滞水 したとしても中央帯が水深1 $1 \mathrm{~mm}$ 以下とできる降雨強度は, 溝が健全の場合で $75 \mathrm{~mm} / \mathrm{h}$ であるのが，溝容積が30\%減少 すると $55 \mathrm{~mm} / \mathrm{h}$ に， 60\%減少すると $20 \mathrm{~mm} / \mathrm{h}$ 程度にまで低下 することがわかる。

降雨時における滑走路上の滞水部分の水深は，グルー ビングの溝形状の保持程度以外にも，きめ深さや横断勾 配によって変わってくる. しかし，ここで示したもの以 外にも横断勾配やきめ深さ等を変えて数多く行った計算 によれば，それらの影響は大きいものではなく，水深を 浅く保持するためには，グルービング溝の形状変化を防 ぐことが肝要であるとわかった.

そこで，降雨時における航空機の走行安全性を確保す るために必要となる滑走路舗装の性能を定め, それを満 足するために必要となるグルービングの溝容積変化率の 限界值を定めることにする。 ここでは，具体的な要求性 能として, 降雨強度 $60 \mathrm{~mm} / \mathrm{h}$ の降雨があった場合に滑走路 中央帯部分の水深を $1 \mathrm{~mm}$ 以下に保持できることとする. この水深 $1 \mathrm{~mm}$ という值は, 前述のように降雨時における 航空機の走行安全性を確保寸るためには可能な限り水深 を浅くしなければならないと実験的にわかったことと，
車両形式の測定装置によるすべり抵抗性測定時の水深を $1 \mathrm{~mm}$ としていること77, 8) に基づいている．また，滑走路 中央帯部分は航空機の走行が集中する範囲である．上記 の計算結果から, この要求性能を満足するためには, グ ルービングの溝容積を $20 \%$ 程度の減少に留めなければな らないことが導かれる。

\section{3. グルービングの安定性に関する室内試験}

2.における考察から，滑走路のすべり抵抗性を確保する ためにはグルービングの溝形状を保持することが肝要で あるとわかった，それを実現するためには変形抵抗性に 優れたアスファルトコンクリートを使用することがまず 必要となるので，その具体的な方法を見出すことを目的 として室内試験を実施した。

\section{(1) 試験計画}

変形抵抗性に優れたアスファルトコンクリートを得る 方法として次の二つの方策について検討した.

1) アスファルトコンクリートの材料自体の工夫

2) 舗装施工後の養生期間経過後のグルービング設置 以下では，それぞれの試験計画を概説する.

\section{a) 材料の工夫}

アスファルトならびに骨材（最大粒径と粒度）をいろ いろ変えてアスファルトコンクリートの試料を作製して 試験に供し，その結果を標準的な材料の場合と比較する ことによってその性状について検討した.

標準的な材料としては，アスファルトとしてストレー トアスファルト60/80を，骨材として空港土木工事共通仕 様書（以下，共通仕様書） ${ }^{16)}$ にある基本施設表層タイプI （最大粒径13mm）の中央粒度のものを使用した.

骨材を変えた場合として，最大粒径を $20 \mathrm{~mm} ， 30 \mathrm{~mm}$ と したものを用いた．20mmについては，表層用のほかに， 基層用の粒度（共通仕様書に規定）を有するものも用い た.

アスファルトを変えた場合としては，ストレートアス ファルトで品質が異なるもの，すなわち針入度が40/60 と 80/100のものと，ゴム，熱可塑性エラストマを使用した改 質I型，改質II型アスファルトを用いた。 これらの4種類の アスファルトのうち, 後述するように, 総合的に優れた 評価が得られた改質II型アスファルトを使用して，骨材を 変えた場合についても検討した。

\section{b) 養生期間の確保}

舖装施工後グルービングを設置するまでの間に，アス ファルトコンクリートが自然環境に暴露されて老化が進 むこと，これに加えてオーバーレイの場合には航空機が 繰り返し走行してアスファルトコンクリートの密化が進 
むことから，それらを再現したアスファルトコンクリー 卜試料を準備して，そのような履歴のない場合と比較・ 検討した. アスファルトコンクリート自体は標準的なも のを使用した。

表層を施工してからグルービングを設置するまでの期 間としては，現地で1，2，3，6ヶ月となるような4種類を 考えた. 舗装が新設されるときはその間航空機の走行が なく，補修工事の場合には走行があるので，これを室内 試験で再現するために，期間を適切に設定して促進老化 作用を与えたほか子, 補修工事用に交通履歴も付与した.

\section{c) 力学性状の確認}

ここで考えた二つの方法の有効性を検証すべく準備し た材料について，グルービング溝の変形抵抗性，すなお ちグルービングの安定性を把握するために, 繰返し載荷 による溝形状の変化を調べた，具体的には，航空機荷重 の繰返し走行による溝のつぶれ・形状消失（変形）と角 久けの二つを取り上げた。これらの現象について室内試 験により検討する方法として, 既往の研究 ${ }^{4), 6)}$ と同様に, ホイールトラッキング試験とラベリング試験を用いた.

\section{(2) 使用材料}

アスファルトコンクリートを構成する材料である，ア スファルトならびに骨材について記してから，配合につ いて述べる.

\section{a) アスファルト}

使用したアスファルトは，ストレートアスファルト， 改質I型, 改質II型である. ストレートアスファルトの場 合は針入度60/80を標準に，40/60と80/100も使用した。い ずれの品質も所定の規格，すなわち，ストレートアスフ アルトはJSの規定, 改質アスファルトは舗装設計施工指 針 ${ }^{17)}$ における標準的性状を満足している.

\section{b) 骨材}

骨材の最大粒径は $13 \mathrm{~mm}$ のものを標準にして，20mm， $30 \mathrm{~mm}$ も用いた，骨材の粒径分布については，共通仕様書 に記載のある $13 \mathrm{~mm} ， 20 \mathrm{~mm}$ の場合は表層の規定範囲（表 層タイプI，密粒度）の中央粒度を用いた。最大粒径 $20 \mathrm{~mm}$ 場合には，これに加えて，基層の規定範囲（粗粒 度）の中央粒度も用いた。 また，共通仕様書に記されて いない最大粒径30mmの場合の粒度は米国の規定 ${ }^{18)}$ に合 致するものを用いた. これらの骨材は関東地方において 一般的に使用されているものであり，材質はいずれも共 通仕様書の規格を満足している.

\section{c) 配合設計}

アスファルトコンクリートの配合については，マーシ ヤル安定度試験に基づいて最適アスファルト量を定める 方法, いわゆるマーシャル法によって決定した.

骨材最大粒径 $13 \mathrm{~mm} ， 20 \mathrm{~mm}$ の場合の配合設計は，共通 仕様書の規定を満足するように行った. すなわち，最大
粒径 $13 \mathrm{~mm}, 20 \mathrm{~mm}$ ともマーシャル安定度試験に対する基 準值は基本施設(1)表層のものを採用した。また，最大粒 径 $20 \mathrm{~mm}$ で基層用粒度の場合には，共通仕様書のマーシャ ル安定度試験に対する基本施設(3)基層の基準も採用した。 最大粒径30mmのものについては，ASTM D3515ならびに 全米アスファルト舗装協会 (National Asphalt Pavement Association)の基準 ${ }^{8)}$ を用いた。 ちな夕にこれらマーシ ヤル安定度試験における基準值の一つである安定度は, 最大粒径 $13 \mathrm{~mm}, 20 \mathrm{~mm}$ で $8.8 \mathrm{kN}$ 以上，最大粒径 $30 \mathrm{~mm}$ では モールド径の違いもあって18.9kN以上となっている.

\section{（3）試供体の準備}

グルービングの安定性を把握するために実施したホイ ールトラッキング試験とラベリング試験の供試体作製方 法について記す.

\section{a) アスファルトコンクリート試料の作製}

供試体は，いずれの試験用も，まずアスファルトコン クリート試料を作製し，必要に応じて，老化，交通履歴 を与えたのち，グルービングを施すことにより作製した. 供試体の寸法はいずれも標準的なものであり，ホイール トラッキング試験用で幅 $300 \mathrm{~mm}$, 長さ $300 \mathrm{~mm}$, 厚さ $50 \mathrm{~mm}$ ，ラベリング試験用で幅 $150 \mathrm{~mm}$ ，長さ $400 \mathrm{~mm}$ ，厚

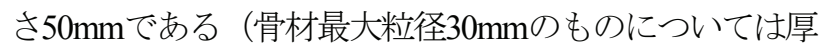
さが100mmである）。

アスファルトコンクリート試料は, 配合試験により得 られた最適アスファルト量を用いて舗装試験法便覧に記 載されている方法に準拠して，ローラーコンパクタを使 用して作製した。 これらの試料の締固め度は最低でも 99.3\%といずれも十分に締固めが行われている.

\section{b) 老化ならびに交通履歴の付与}

作製したアスファルトコンクリート試料の一部には老 化履歴もしくは老化ならびに交通履歴を与えた．前者は アスファルトコンクリート施工後グルービングを設置す るまでの間の自然環境の作用による劣化を，後者はそれ に加えて交通荷重の繰返し作用による劣化を想定したも のである.

老化履歴はアスファルトコンクリートを高温下で酸化 させる促進老化方法を採用した，具体的には $60^{\circ} \mathrm{C}$ に調整 した恒温槽 (真空乾燥炉) 内に，アスファルトコンクリ 一ト試料を入れ，酸素を充満させて 6 時間放置するという サイクルを2～12サイクル繰り返す方法（促進老化時間で 12〜72時間となる）である. 既応の研究 ${ }^{19)}$ によれば，放 置時間を24時間とした促進老化を4サイクル繰り返した場 合に供試体に与えられる老化作用が，9ケ月の自然環境下 で暴露したものと同等であることがわかっている。した がって，ここで用いた方法による老化は，(1)で記したよ うに，1〜6ケ月程度の自然環境下での老化に相当するこ とになる. 
交通履歴による劣化は，外径 $202 \mathrm{~mm} ，$ 幅 $45 \mathrm{~mm}$ ，輪荷重 $700 \mathrm{~N}$ ，接地圧 $320 \mathrm{kPa} の$ 載荷車輪を，アスファルトコンク リート試料の幅 $150 \mathrm{~mm}$ 範囲にわたって均一に分散させ ながら走行させることによって与えた（いわゆるトラバ 一ス走行）。具体的には，促進老化が1サイクル終了する たびに，すなわち老化時間6時間ごとに，載荷車輪を700 回走行させることにより与えた. すなわち老化時間が 12 〜 72時間で，1,400～8,400回の交通履歴になる. これは, 航空機の離着陸数に関する最近の調査結果を参考に，わ が国の空港滑走路の1日あたりの離陸，着陸回数をそれぞ れ平均で 60 回 ${ }^{20)}$ とし, 航空機の車輪数とカバレージ換算 係数ならびにここで用いた試験における車輪幅とトラバ 一ス幅に基づいて決定したものである.

\section{c) グルービングの設置}

グルービングは試料転圧方向と直角に，幅 $6 \mathrm{~mm}$, 深さ $6 \mathrm{~mm}$ の溝を $32 \mathrm{~mm}$ 間隔で試料中央部に7本設置した（図-5 参照）。このときには，実際の場合と同様に，ダイヤモ ンドカッターを用いてグルービングを施工した．なお， 老化履歴もしくは老化ならびに交通履歴を付与する場合 は，履歴を与えてからグルービングを施したことは言う までもない.

グルービング施工後, グルービング溝の幅, 深さ, 容 積を計測した。幅と深さは，7本の溝の供試体中心線上で ノギスを使用して測定した。また，溝の容積は7本の溝の 供試体中心線に沿った幅 $50 \mathrm{~mm}$ もくは100mmの範囲で測 定した（測定幅 $50 \mathrm{~mm} ， 100 \mathrm{~mm}$ はそれぞれホイールトラッ キング試験用，ラベリング試験用）。具体的には，供試 体中心線から左右 $25 \mathrm{~mm}$ もくは $50 \mathrm{~mm} の$ 位置の外側に粘 土を詰めて内側の溝にだけ砂が入るようにして砂の量を 測定し，その単位体積質量を用いて溝の容積を計算した。 このときに使用した砂は0.3mmふるいを通過し， $0.15 \mathrm{~mm}$ ふるいに留まるものである.

\section{(4) 試験方法}

ここで用いた二つの試験方法について，その詳細を記 述する。

\section{a) ホイールトラッキング試験}

ホイールトラッキング試験は，舗装試験法便覧に示さ れている方法に準拠して載荷重700Nのソリッドタイヤを 使用して行った。ただし，試験温度は $40^{\circ} \mathrm{C}$ 変更してい る. これは, 予備試験の結果, 試験温度を標準の $60^{\circ} \mathrm{C}$ と するとグルービングの溝形状の保持方策によるグルービ ングの変形抵抗性の違いが明確にならないことがわかつ たので，それらの方策の有効性を評価するために試験結 果に相対的な違いが生ずることを期待して採用したもの である. 走行載荷は5,000回まで実施し，所定の走行回数 時にグルービング溝の幅，深さ，容積を測定した．その 方法は供試体作製時と同じである.

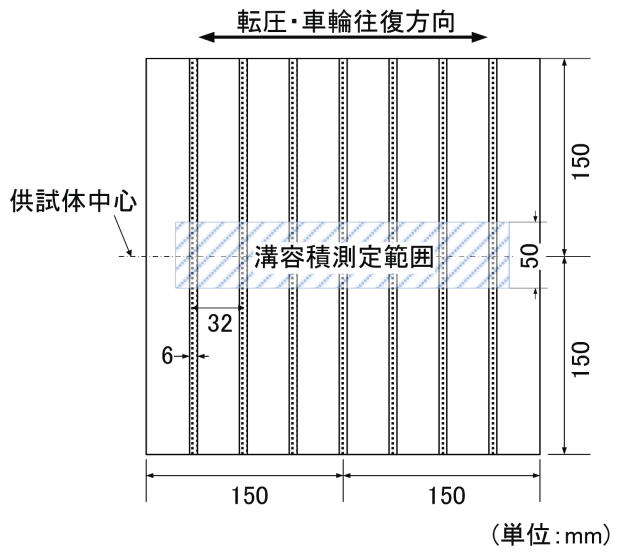

a) ホイールトラッキング試験用供試体

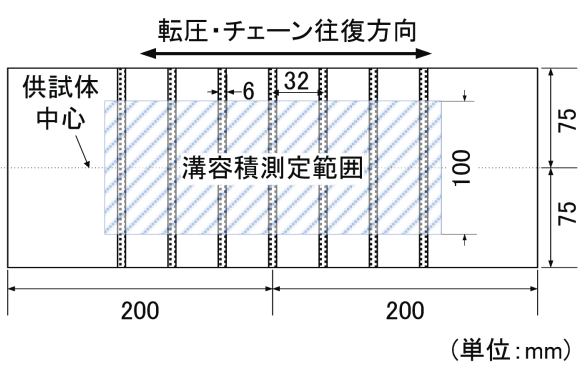

b) ラベリング試験用供試体

図-5 試供体平面図

グルービングの溝の変形の程度を表す変化率 $l$ は次式に より定量化した。

$$
l=\frac{a-a^{\prime}}{a} \times 100(\%)
$$

ここに

$a$ : 試験前における溝の幅, 深さまたは容積,

$a^{\prime}$ : 試験後における溝の幅, 深さまたは容積.

\section{b) ラベリング試験}

ラベリング試験は，ホイールトラッキング試験の条件 設定と同様の観点から試験温度を $0^{\circ} \mathrm{C}$ と変更したほかは舗 装試験法便覧に準拠して往復チェーン方式で行った。試 験開始後所定の時間経過時に，ホイールトラッキング試 験の場合と同じ方法によりグルービング溝の幅，深さ， 容積を測定した.グルービング溝の変形程度はホイール トラッキング試験と同様に式(1)によって定量化した。な お，容積測定時にその範囲を $100 \mathrm{~mm}$ としているが，これ は試験においてチェーンを使用するため, 比較的広い範 囲が削られるからである.

\section{c) 試験結果の評価}

ホイールトラッキング試験，ラベリング試験の方法は, いずれも，試験温度が舗装試験法便覧に示されている標 準的なものとなっていないが，これは，a)でも記したよ うに，グルービング溝形状の保持性能について相対的な 


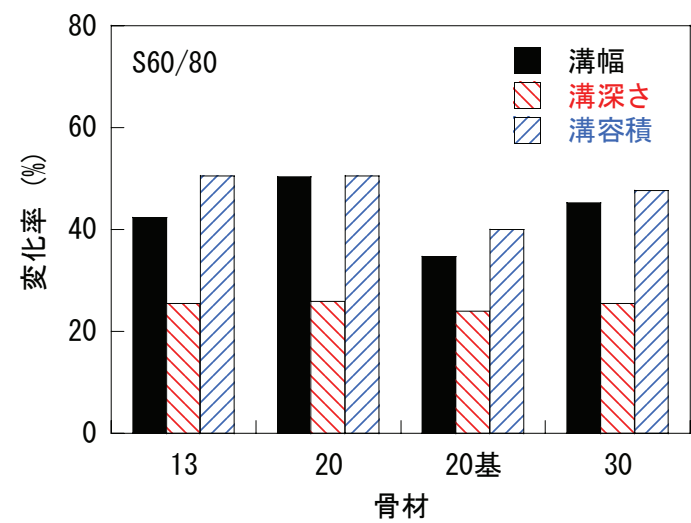

図-6 溝変形に対する骨材の影響

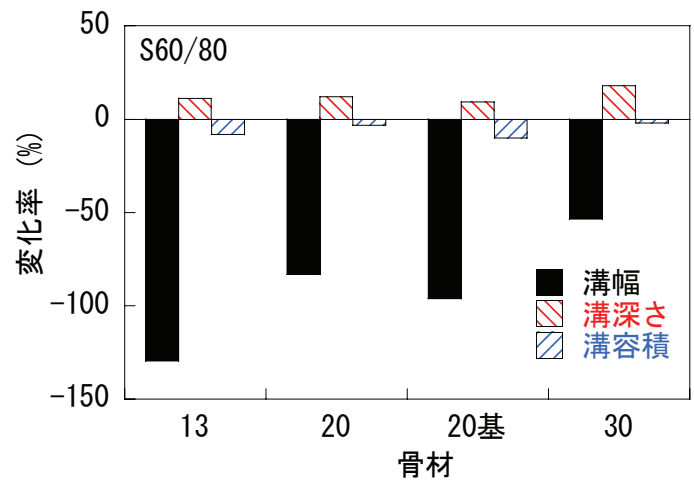

図-7＼cjkstart角欠けに対する骨材の影響

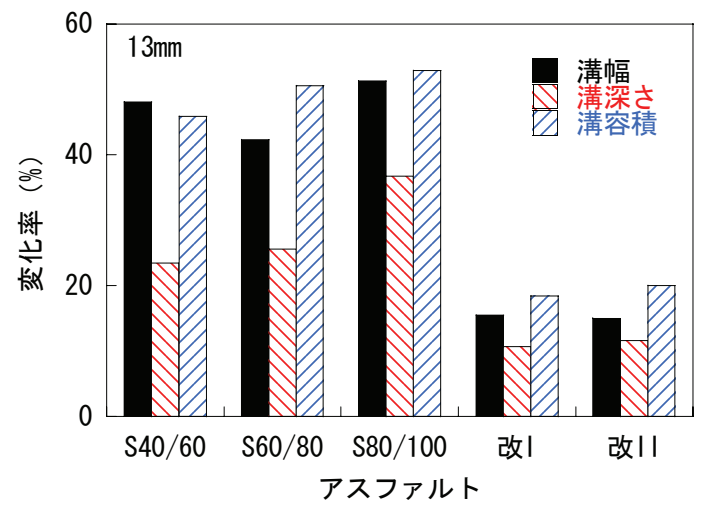

図-8＼cjkstart溝変形に対するアスファルトの影響

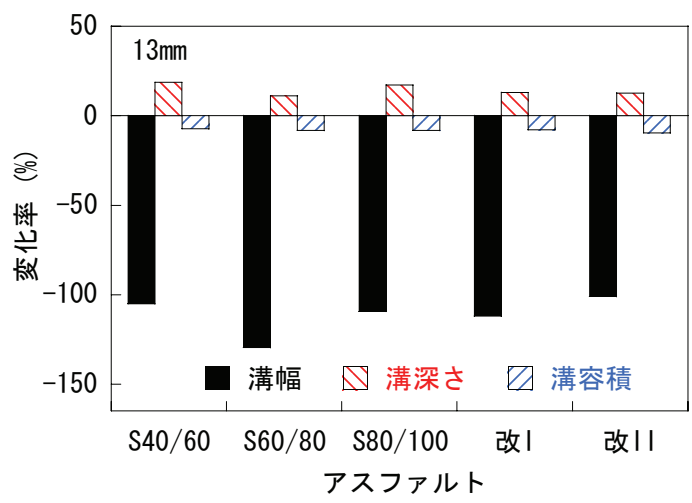

図-9 角欠けに対するアスファルトの影響
評価が行えるように変更したものである．これらの試験 は，車輪もしくはチェーンを供試体表面に所定の回数繰 り返し作用させるものである. 後者の方法により摩耗抵 抗性を調べた研究では試験の初期段階における性状に注 目して性能評価をしている ${ }^{21)} も の の ，$ 供用後できるだけ 長期間経過した時点での性能を評価したいことから，こ こでは両試験とも試験終了時の最終的な溝形状の変化に 注目することにした.

以下では，この方針に従って，グルービング形状に対 する要求性能を満足するために必要となる，アスファル トコンクリートが具備すべき品質について考察を加える. なお，両試験中のグルービング溝形状の変化過程につい ては別途詳述している ${ }^{22)}$.

\section{4. グルービングの溝形状の保持方策}

室内試験の結果をまとめて，グルービングの溝形状を 保持するための方策について考察する.

\section{(1) 材料の工夫によるグルービング安定性確保}

アスファルトコンクリートの材料そのものの工夫につ
いては，骨材とアスファルトに注目して室内試験を実施 した.

\section{a) 骨材の影響}

骨材 (最大粒径と粒度) が異なる場合の溝の変形しや すさについて，図-6にホイールトラッキング試験の結果 を示寸，骨材の違いでは，基層用20mmのものの性能が若 干良好なようであるが，あまり明確にはなっていない．

角欠け抵抗性を明らかにするために実施したラベリン グ試験の結果を図-7に示寸、いずれの場合をみても，チ ェーンにより供試体表面が広く薄く削られる，すなわち 溝幅が増加して, 溝深さが減少するという傾向は認めら れるものの, 溝容積自体の変化は非常に小さい，骨材に よる違いをみると，最大粒径の大きいものほど，溝幅の 拡大は抑えられるが，その分溝深さは浅くなる，寸なわ ち狭い範囲を浅く削るようになることがわかる.

\section{b) アスファルトの影響}

アスファルトが異なる場合のホイールトラッキング試 験の結果を図-8にまとめた．改質アスファルトを用いる ことにより, 溝の変形に対する抵抗性は著しく向上寸る ことがわかる，ストレートアスファルトでは，針入度の 小さいものが溝の変形に対する抵抗性は良好なようであ るが，改質アスファルトにははるかに及ばない． 


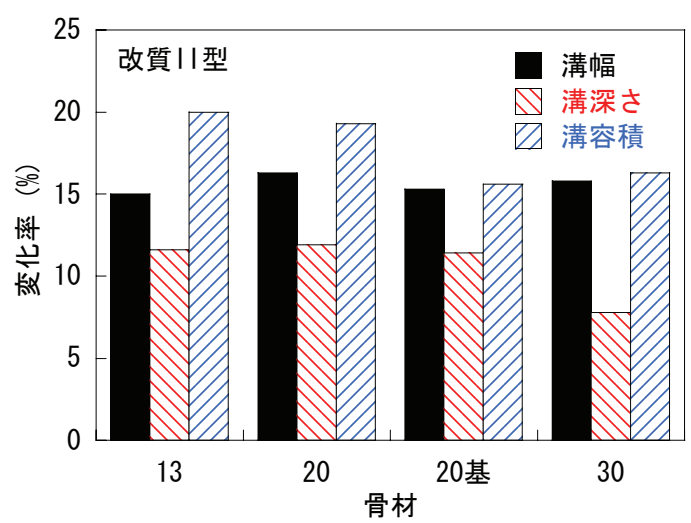

図-10＼cjkstart溝変形に対寸る骨材の影響(改質II型)

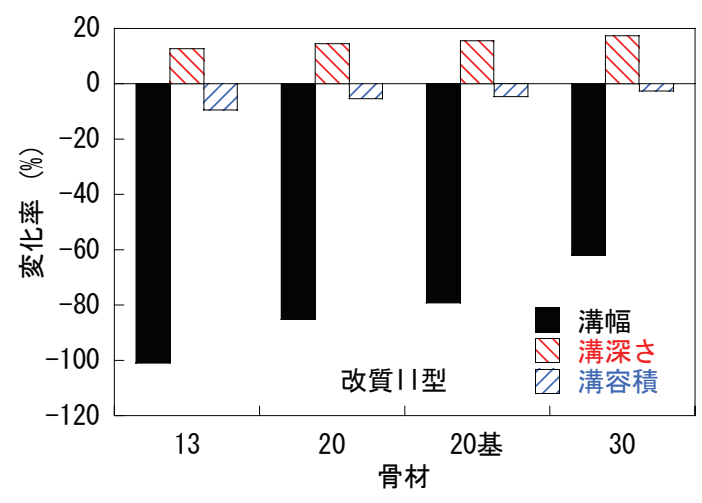

図-11 角欠けに対寸る骨材の影響(改質II型)

ラベリング試験の結果を図-9にまとめた。 ホイールト ラッキング試験とは異なり，改質アスファルトを使用す ることによっても角欠け抵抗性にはあまり変化が認めら れない.

改質アスファルトを用いることによりグルービングの 溝の変形に対する抵抗性は増大するが，改質I型とII型の 違いについてはあまり明確にはなっていない. 前者は摩 耗対策，後者はわだち掘れ対策として開発されたもので あり，空港舗装では摩耗に比べるとわだち掘れが顕著な 損傷状態で，近年改質II型が使用されることも多くなって いるので，ここでは改質II型を使用して骨材の種類を変え た場合について検討した。 ホイールトラッキング試験結 果を図-10に示す. これから, 最大粒径 $30 \mathrm{~mm}$ のものが, 若干ではあるが，良好な性能を示すことがわかる. 図-11 に示した角欠けについては，ストレートアスファルトを 用いて骨材の影響を調べた場合と同様の傾向，すなわち， 最大粒径の大きい骨材を用いたもののほうが，溝幅の拡 大が小さく, 溝深さが浅くなっているとの傾向がみられ る.

\section{c) まとめ}

以上の結果をまとめると, アスファルトコンクリート の材料そのものを工夫することによりグルービングの安 定性を確保する方策については，次のことが考えられる.

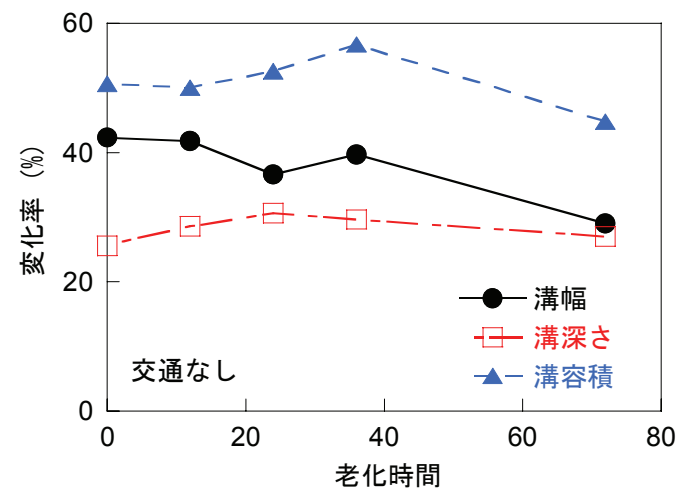

図-12 溝変形に対する新設時養生期間の効果

1) 骨材の最大粒径ならびに粒度がグルービングの溝の変 形抵抗性に及ぼす影響はあまり明確ではないものの, 最大粒径の大きいものがいくぶん有利である.

2) アスファルトとして改質アスファルトを使用すること は，グルービングの安定性を向上させるためには非常 に効果がある.

3) 溝容積変化率を20\%以内に抑えるという観点からは, 改質アスファルトの使用が必須であり，これに加えて 最大粒径の大きな粒度の骨材を使用することでさらに 有利になる.

\section{(2) 養生期間の確保によるグルービングの安定性確保}

標準的な材料（ストレートアスファルト60/80, 最大粒 径 $13 \mathrm{~mm}$ ・表層用中央粒度の骨材の組み合わせ）を用いた 場合, 表層アスファルトコンクリート施工後にグルービ ングを設置するまでに養生すべき期間について，新設時 とオーバーレイ時に分けて検討した.

\section{a) 新設時}

図-12には，溝の変形抵抗性を明らかにするために実施 したホイールトラッキング試験の結果をまとめた. 溝幅 の変化率は老化時間の増加につれて低下する傾向がみら れるものの, 溝深さにはあまり変化がみられない. 結果 として, 養生期間の増加につれて溝容積の変化率は減少 することがわかる.

角欠け抵抗性について検討するために実施したラベリ ング試験の結果を図-13に示した．養生期間を長くとるこ とにより溝幅の拡大は抑えられる傾向がみられるが, 溝 深さにはあまり変化がない。

\section{b) オーバーレイ時}

図-14にはホイールトラッキング試験結果である溝の変 形抵抗性を示した。 この場合は，老化と交通履歴の両方 の作用を受けることにより，溝の幅，深さならびに容積 の変化率，特に幅と容積の場合はかなりの程度小さくな り，グルービング溝の変形抵抗性が明らかに向上してい ることがわかる。その程度は上述の新設時の場合よりも 大きいものとなっている. 


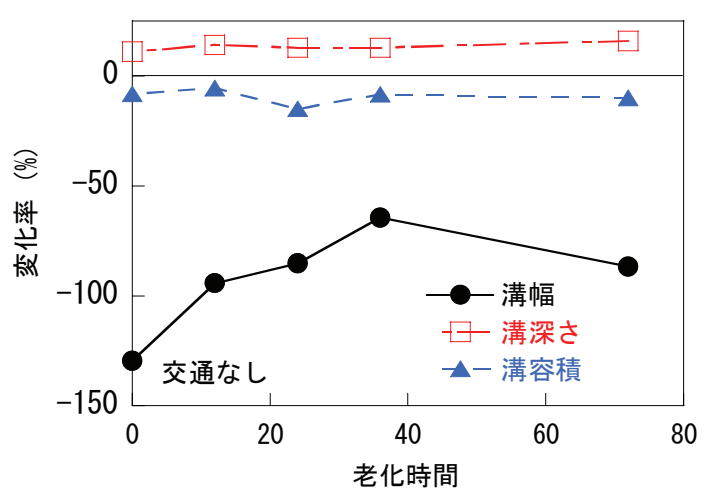

図-13 角欠けに対する新設時養生期間の効果

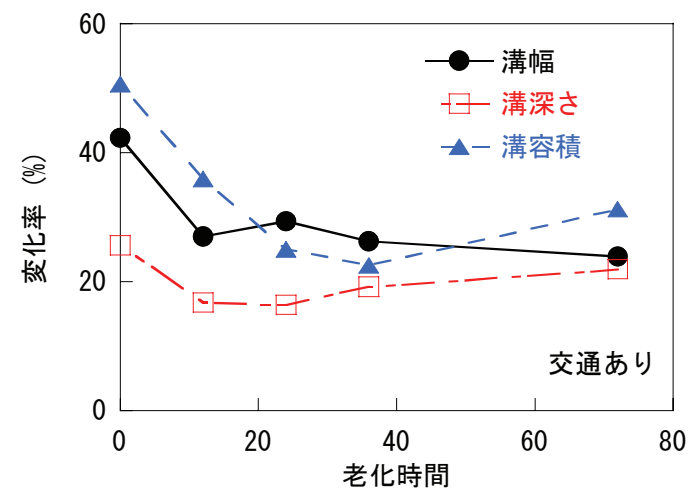

図-14 溝変形に対する補修時養生期間の効果

ラベリング試験結果である角欠けについて図-15に示し た. 養生期間の増加につれて溝幅の変化率は徐々に低下 している傾向がみられるものの，全体的にはあまり変化 していない.

ホイールトラッキング試験終了時の溝容積変化率につ いて，交通履歴のない場合（新設時）とある場合（才一 バーレイ時）で比較したものが図-16である，交通履歴の ない場合には養生期間を長くとっても変化率には大きな 差は出てこないが，交通履歴を与えた場合には養生期間 を長くとることによって変化率は大きく低下してくるこ とが明らかである。

\section{c) まとめ}

以上のことより，表層アスファルトコンクリート施工 後グルービングを設置するまでの養生期間を確保するこ とによりグルービングの安定性を確保する方策について は，次のようにまとめられる。

1) 交通履歴のない新設時の場合には，養生期間を確保す ることによりわずかではあるがグルービングの溝幅の 変化が抑えられる傾向がみられる.

2) 交通履歴のあるオーバーレイ時の場合には，養生期間 を確保することによりグルービングの安定性は大きく 向上する。

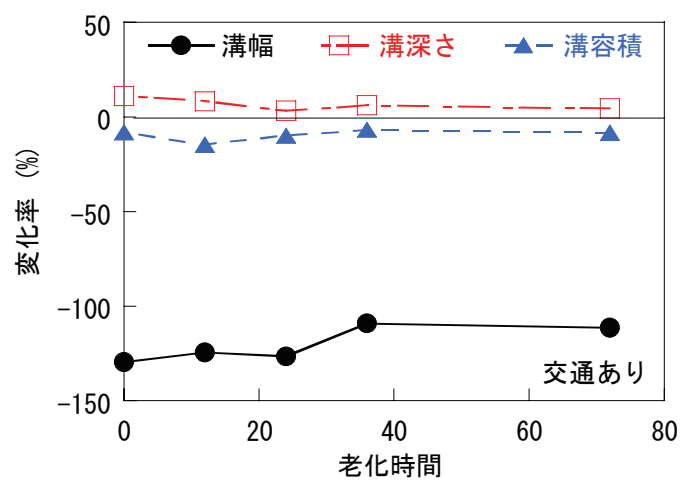

図-15 角欠けに対する補修時養生期間の効果

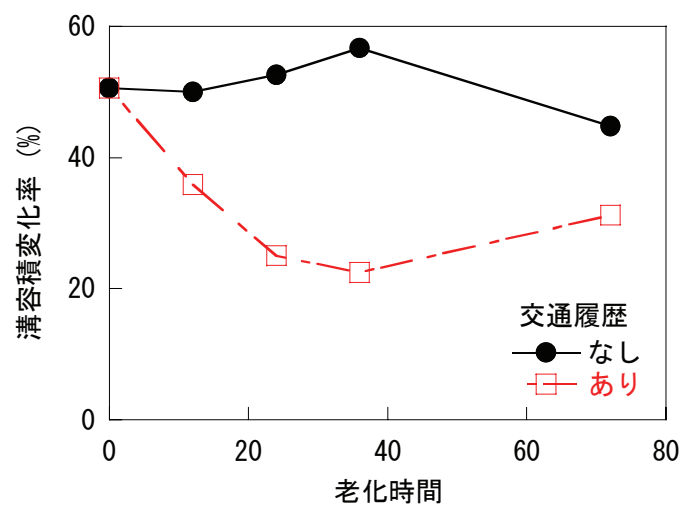

図-16 新設時とオーバーレイ時における養生効果の違い

3) 標準的な材料を使用する場合，養生期間を確保するこ とによって溝容積変化率を $20 \%$ 以内に抑えるという方 策は，新設，オーバーレイ時のいずれにおいても採る ことはむずかしい，しかし，材料を変えた場合の検討 結果からわかるように，最大粒径を比較的大きくした 粒度の骨材を用いるといったように材料や配合を工夫 すれば，特にオーバーレイ時にはこの方策を採ること も可能と考えられる.

\section{(3) 滑走路のすべり抵抗性の確保方策}

上記の試験結果を総括して, 滑走路のすべり抵抗性を 確保するための方策として，降雨時に所定の範囲の水深 を浅く保持するために必要となるグルービング溝形状の 確保方策についてまとめる．以下では，3.で記したように， 降雨時のすべり抵抗性を確保するためにはグルービング 溝形状の変化率を20\%以下に抑える必要があるとの前提 に立って，これを満足するための方策について示す。こ の場合, ホイールトラッキング試験, ラベリング試験と も, 試験終了時の溝形状の保持状況を性能評価における 指標と見なしている.

アスファルトコンクリート材料自体の工夫による方策 を考えると，ラベリング試験により検討した角久けに対 
する抵抗性については, いずれの材料もほとんど問題な く満足できることが明らかである。これに対して，ホイ ールトラッキング試験により検討した溝形状の変形抵抗 性については, 改質アスファルトを使用寸ることが必要 となることがわかった.ささら，その場合であっても， 最大粒径の大きな粒度分布の骨材を使用寸ることが望ま れる.

表層アスファルトコンクリート施工後にグルービング を設置するまでの養生期間を確保するという方策につい ては，ストレートアスファルト60/80 と密粒度骨材による 標準材料を使用するとした場合, 新設時, オーバーレイ 時とも実用的にはむずかしいとわかった。 しかし，最大 粒径を比較的大きくした粒度の骨材を用いるといったよ うに骨材，アスファルトやその配合を工夫することによ って，特にオーバーレイの場合にはこの方策を採用する ことも可能と考えられる.

\section{5. まとめ}

湿潤時における空港滑走路上の航空機の走行安全性を 確保するために必要となる, グルービングの安定性確保 方策を検討するために実施した室内試験結果は次のよう にまとめられる.

1) アスファルトコンクリートの骨材に注目寸ると，最大 粒径の大きいものを用いることが溝形状の変化を小さ くする点ではいくぶん効果がある.

2) アスファルトコンクリートのアスファルトに注目する と，改質アスファルトを使用することがグルービング の溝形状を保持する上では非常に有利である.

3) 表層施工後グルービングを設置するまでの養生期間を 長くとることによりグルービングの安定性は向上する. 特に，オーバーレイ時においてその効果は大きい.

以上の試験結果に加え, 現地調査ならびに降雨時にお ける滑走路の滞水状態に関する数值解析の結果に基づく と，グルービングの溝形状を確保するための方策として は改質アスファルトを使用することが必要であると結論 づけられる. ただし，オーバーレイ時には，ストレート アスファルトを用いた場合でも，最大粒径を比較的大き くした粒度の骨材を用いるといった材料面での工夫をす ることにより，ある程度の養生期間を確保することで対 応可能と考えられる.

\section{6. おわりに}

本論文では，室内試験によってグルービングの安定性 について検討した. いくつかの仮定を設けることによっ
て, グルービングの溝形状の保持程度に関する要求性能 を明確にし，それを満足するとの観点からグルービング の安定性確保方策について取りまとめた。 今後は, 現地 空港での試験を行うなどして本研究成果を検証するとと もに, 空港舗装を対象にした室内試験方法についても整 備していく必要があると考えている.

本研究の遂行にあたっては, 東京航空局東京空港事務 所の皆様に多大なご協力をいただきました．ここに謝意 を表します。

\section{参考文献}

1) 国土交通省航空局（監）：空港土木施設設計基準, 港湾空港建設技術サービスセンター, 2001.

2) 八谷好高, 梅野修一, 藤倉豊吉 : 空港滑走路のすべり抵抗 性, 土木学会, 舗装工学論文集, 第 1 巻, pp. 159-166, 1996.

3) 運輸省航空局（監）：空港土木施設施工要領，(財）港湾 空港建設技術サービスセンター, 1999.

4) 佐藤勝久, 福手 勤, 佐藤峰夫 : 空港アスファルト舗装に おけるグルービングの安定性に関する研究, 港湾技研資料, No.308, 24p., 1978.

5) 運輸省大阪航空局 : グルービング補修材料調查報告書, $103 p ., 1981$.

6) 運輸省第二港湾建設局東京空港工事事務所 : 東京空港グル ービング性状調査報告書, 143p., 1986.

7) ICAO: Aerodromes, Volume 1, Annex 14, 2004.

8) (財）航空保安協会 : グルービング滑走路の安全性に関す る第二次調查研究報告書, 101 ., 1986.

9) ICAO: Airport Services Manual, Part 2, Pavement Surface Conditions, 1984.

10）（社）日本道路協会 : 舖装試験法便覧, 1069p., 1979.

11) 安部裕也, 亀山修一, 玉井昭典, 笠原 篤, 斎藤和夫 :

Circular Texture Meter (CTM) と DF テスタによる国際摩擦指 標(IFI)の算出, 土木学会, 舗装工学論文集, 第 4 巻, pp.1522, 1999.

12）（社）日本道路協会 : 舗装試験法便覧別冊, 317p, 1996.

13) Pelloli, R.: Road Surface Characteristics and Hydroplaning, Transportation Research Record, No.624, pp.27-32, 1976.

14) 酒井秀夫 : タイヤ工学, 426p., グランプリ出版, 1987.

15) Reed, J.R., Kibler, D.F. and Proctor, M.L.: Analytical and Experimental Study of Grooved Pavement Runoff, DOT/FAA/PM-83/34, 65p., 1983.

16) 国土交通省航空局（監）: 空港土木工事共通仕様書,

（財）港湾空港建設技術サービスセンター，2001。

17）（社）日本道路協会 : 舗装設計施工指針，333p., 2001.

18）日本道路建設業協会技術振興委員会海外技術資料部会 : マ ーシャル配合設計手法を用いた大粒径混合物の試験評価(1), 道路建設, 3/5, pp.86-91, 1991.

19) 野村健一郎・丸山暉彦・高橋光彦 : アスファルトの劣化促 
進方法に関する研究，土木学会，舗装工学論文集，第 1 巻, pp.223-230, 1996 .

20）国土交通省航空局（監）：数字でみる航空 2005，2005.

21) 早野公敏, 高橋光彦 : グルービングの摩耗抵抗性の評価に 関寸る一検討, 土木学会第 60 回年次学術講演会, 5-097, pp.193-194, 2005.

22) $\mathrm{Wu}, \mathrm{S} .$, Hao, P. and Hachiya, Y.: Laboratory Evaluation on Durability of Grooving for Airport Runways, 土木学会, 舗装工 学論文集, 第 7 巻, pp.30/1-7, 2002.

(2006.4.24 受付)

\section{DURABILITY OF GROOVING IN RUNWAYS FOR AIRCRAFT LOADS}

\section{Yoshitaka HACHIYA and Yukitomo TSUBOKAWA}

The effectiveness of grooving, in which transverse grooves are formed on the surface to increase the skid resistance, is reduced with the deficiency such as the collapse of the grooves due to heavy aircraft loads. As aircraft become larger and operation frequency increases, the grooves suffer deterioration such as loss of groove volume at high temperature and wearing of asphalt concrete at low temperature. To investigate the durability of the grooving against heavy-duty aircraft loads, a series of laboratory tests was conducted. As a result, modified asphalt is recommended for both new construction and overlay construction. Straight asphalt is, however, applied to overlay construction when a longer period is secured before groove installation. 